\author{
A.D. Vetrova ${ }^{1,2}$ \\ ${ }^{1}$ Pirogov Russian National Medical Research University of the Ministry of Health of Russia, \\ Moscow \\ ${ }^{2}$ Central children's teaching hospital of the Federal Biomedical Agency of Russia, Moscow
}

\title{
Acute tonsillitis in children: a pediatrician's perspective
}

\section{Author affiliation:}

Vetrova Anna Dmitrievna, assistant at the intermediate level pediatrics department \#1 of the Faculty of Pediatrics of the Pirogov RNMRU of the Ministry of Health of Russia, pediatrician at the CCTH of the Federal Biomedical Agency of Russia (Federal State Budgetary Healthcare Institution)

Address: 1 Ostrovityanova Str., Moscow, 117997, tel.: +7 (916) 5431831 , e-mail: a.d.vetrova@gmail.com

Article received: 11.12.2013. Accepted for publication: 24.02 .2014 .

This article is dedicated to one of the most widespread pathologies in children-acute tonsillitis, which is a daily routine for both otolaryngologists and pediatricians. The authors analyze etiology and morphology of acute tonsillitis in children of various age groups. They revealed that the main complaint of pediatric patients is a sore throat. The authors present modern approaches to diagnostics and treatment of acute tonsillitis induced both by Group $A \beta$ hemolytic streptococcus and various viruses. In this article, they consider the possibility of using local treatment to treat inflammatory oropharyngeal diseases in combination with systemic antibacterial drugs and as monotherapy of acute throat pain. The authors substantiate use of throat lozenges with antiseptic and analgesic effects. They note effectiveness, safety and pharmacoeconomic advantages of a local antiseptic, anti-viral and anti-fungal drug. These aspects are of utmost importance to the choice of an antiseptic given that it is a non-prescription drug.

Keywords: acute tonsillitis, children, therapy, local treatment, cetylpyridinium chloride.

Onset of the cold season in Russia is traditionally characterized by a surge in upper respiratory tract infections, which pose a serious problem for public health due to their wide spread and the associated economic damage suffered both by individuals and the society at large. Despite the fact that most such diseases take a mild course, they aggravate the children's well-being and impede activities of daily living [1].

Without any doubt, pharyngeal lymphoid tissue - a part of the integrated immune system of the body, its outpost - plays the leading role in the development of inflammatory oropharyngeal diseases $[2,3]$. The main operating link of the lymphoepithelial Waldeyer's tonsillar ring is palatine tonsils. Located in the chiasm of the respiratory and digestive tracts, palatine tonsils directly contact with the various antigens entering the body, whereas the anatomic peculiarity (tortuous crypts) provides a long-term contact of the exogenous stimulating agent with the organ cells, which is required for generation of specific and non-specific biologically active substances and cellular elements (lysozyme, interferon, interleukins, immunoglobulins A, M, G, lymphocytes, plasma cells, macrophages), which are secreted into the pharyngeal lumen and then spread all over the body hematogenously and lymphogenously $[4,5]$. Reduced resistance of the upper respiratory tract to continuous attacks of both pathogenic and opportunistic microbes results in frequent episodes of acute inflammatory infections, which not only otolaryngologists, but also pediatricians face in their everyday practice.

Acute tonsillitis is a widespread inflammatory upper respiratory tract infection in children characterized by inflammation of one or several lymphadenoids of the tonsillar ring (usually of palatine tonsils). According to the International Classification of Diseases ( $10^{\text {th }}$ revision), the 
American Association of Otolaryngology widely uses term "tonsillopharyngitis", which indicates lesion of the main oropharyngeal walls without focusing on pharyngitis. Acute infection of the lymphoid tissue is usually referred to as "acute tonsillitis" in Russian and in Europe [6].

Acute tonsillites usually develop in children over 1-1.5 years of age due to completion of the tonsillar ring's lymphoid tissue by that age. In the children under 3-4 years of age, tonsillites are of viral or virobacterial etiology (adenoviruses, Coxsackie enteroviruses etc.) in ca. 95\% of cases. The group A $\beta$-hemolytic streptococcus (Streptococcus pyogenes, GABHS) plays a significant role in the development of acute tonsillitis in children over 4 years of age; it is the leading cause of acute tonsillites and tonsillopharyngites until the age of 18 years (tb. 1) [7-9].

Extensive research materials on the receptor function of tonsils and neuroreflex connections thereof with viscera. Pharyngeal mucosa, especially of posterior and lateral walls, features abundant sensitive innervation. That is why pathological processes in the oropharynx are accompanied by rather troublesome symptoms in ill children - pain, pharyngoxerosis, sense of a foreign body, discomfort and throat irritation.

Pharyngalgia is, perhaps, the most frequent symptom troubling the patients. This complaint is more typical of the children over 4 years of age, as younger children are unable to clearly determine pain localization or evaluate their sensations as painful. The pain symptom is hard to endure for children at large: sometimes children are afraid of swallowing and thus have difficulties with eating and drinking; sleep, mode and well-being become worse. This inevitably leads to deceleration of reparative processes and recovery slowdown. That is why treatment of acute oropharyngeal inflammations and search for the optimal means of terminating pain syndrome in children are relevant [10].

According to various authors, pharyngalgia is the most frequent cause of use of antibacterial drugs, although, according to the Russian and international recommendations, antibacterial therapy at acute tonsillitis is indicated if streptococcal etiology of the disease is proved [11]. Antibacterial therapy at acute tonsillitis is aimed not only at liquidation of clinical manifestations of the disease, but also at GABHS eradication from the oropharynx, as the latter prevents spread of the causative agent and development of complications. Penicillins, cephalosporins, macrolides and lincosamides are used to treat streptococcal tonsillitis and tonsillopharyngitis. According to the Russian and foreign studies, $S$. pyogenes is characterized by high sensitivity to penicillins and cephalosporins [12]. However, $\beta$-lactams are the only class of antibiotics not tolerable by the GABHS.

Timely and correct diagnosis of streptococcal tonsillitis and the further adequate antibacterial treatment contribute to the prevention of acute rheumatic fever and purulent complications [13, 14]. Only express test or culture examination of the ill child's oropharyngeal swab give an unambiguous answer regarding etiology of tonsillitis or tonsillopharyngitis. This approach is deemed the "gold standard" of examination of patients complaining of pharyngalgia. Systemic antibacterial therapy is usually not indicated in the event of a non-complicated course of the disease and no evidence of streptococcal etiology of the inflammatory process. Ill children are usually prescribed topical symptomatic treatment along with antibacterial drugs in such cases and in the event of complex treatment $[10,15]$.

It is often difficult to choose an optimal drug, as the Russian market is largely filled with the marketed drugs. The modern arsenal of symptomatic agents consists of various topical preparations (sprays, slowly disintegrating tablets, lozenges, mouthwashes containing one or several antiseptics [chlorhexidine, hexetidine, benzydamine, ambazone, thymol and thymol derivatives, alcohols, iodine preparations etc.], essential oils, anesthetics [lidocaine, tetracaine, menthol], antibiotics [framycetin] or sulfanilamides and deodorants). They may also contain bacterial lysates, natural antiseptics (herbal extracts, beekeeping products), synthesized mucosal non-specific protection factors featuring antiviral action (lysozyme, interferon) and vitamins (ascorbic acid). Impact of drugs for pharyngalgia-accompanied inflammatory upper respiratory 
tract diseases on the child's body must be taken into consideration; only the most efficient and safe drugs ought to be used in pediatric practice.

The main requirements to the drugs spread over mucosae are as follows:

- wide antimicrobial spectrum, including antiviral and antifungal activity (preferably);

- no toxic effect and low rate of absorption from mucosae;

- low allergenicity;

- no mucosa-irritating effect;

- good organoleptic properties;

- ease of use.

Prescription of a range of drugs is limited due to high allergenicity and irritant action thereof; these include preparation containing iodine derivatives, propolis or sulfanilamides. It ought to be mentioned that the drugs containing plant antiseptics and essential oils are contraindicated to children with atopic disease [16-18].

Lozenges Septolete Neo (KRKA, Slovenia) feature all the aforementioned positive properties. This drug is successfully used in 27 countries; in the Russian Federation it has been used for more than 8 years; it contains an antiseptic agent cetylpyridinium chloride, which features antimicrobial, antifungal and viricidal action (tb. 2). The drug is supplied in the form of lozenges with lemon, apple or sweet cherry flavor, as children often refuse to take "unsavory" drugs. Lozenges alleviate odynophagia and subjective discomfortable sensations, such as throat irritation [19].

Cetylpyridinium chloride is a quaternary ammonium compound antiseptic functioning as a cationic detergent: ammonium ions penetrate the bacterial cell's surface and bond with the microbial cytoplasmic membrane. Cytoplasmic membrane becomes penetrable for low-molecular components, such as potassium ions. Thus, quaternary ammonium components penetrate the bacterial cell and ultimately disturb function thereof; this results in death of the cell.

High surface activity of cetylpyridinium chloride helps the antiseptic to quickly penetrate fissures and lacunae of palatine tonsils; this is an important factor for preventing secondary infections.

The best drugs for pharyngalgia in children are slowly disintegrating tablets and lozenges: unlike other dosage forms, these drug delivery methods allow the active factor to efficiently affect the whole oropharyngeal mucosal surface, including the hard-to-reach areas. Use of topical drugs in the form of mouthwashes may pose difficulties in children, as it requires the ability to hold breath and not to swallow the drug during gargling. Lozenges are designed for resorption; this significantly decreases the risk of the drug's systemic action. It has been proved that prolonged resorption of a lozenge leads to abundant salivation and, therefore, a longer impact of active components on mucosae; this improves the drug's efficacy, whereas the risk of overdose or development of side effects is minimal [2].

Among the preparations for topical treatment of moderate pharyngalgia at acute tonsillitis marketed through pharmacy organizations there are drugs of various price categories, which is highly significant for the choice of an antiseptic as it is sold over the counter. Pharmaceutical market research results allow classifying Septolete Neo as a medium- or moderately high-price drug [20]. As safety, therapeutic efficacy and economic benefit are proved and rather significant for parents of small patients, a pediatrician must remember about age restrictions, contraindications and prevent self-medication and uncontrolled drug intake by the patients.

Lozenges with cetylpyridinium chloride may be used in children over 4 years of age: they should be slowly resorbed until complete disintegration (1 lozenge per 6 hours). Children over 10 years of age are recommended to take up to 6 lozenges per day; children over 12 years of age 1 lozenge per 2-3 hours (not more than 8 lozenges per day). Lozenges should not be taken immediately prior to food intake or with milk. 
Given high pain sensitivity of children, it is extremely important to thoroughly examine the child to establish the correct diagnosis and select drugs. That is why prescription of an antiseptic drug containing cetylpyridinium chloride with high safety profile to children with acute tonsillitis appears to be the optimal approach and may be recommended for both complex treatment in combination with a systemic antibacterial drugs and topical therapy of moderate pharyngalgia. Marked antimicrobial, antifungal and viricidal action is perfectly combined with a moderate anesthetic effect, fine gustatory qualities and ease of use; this allows using the drug as one of the means of treating acute tonsillitis in children.

\section{REFERENCES}

1. Baranov A.A., Gorelov A.V. etc. Ostrye respiratornye zabolevaniya u detei: lechenie $i$ profilaktika. Nauchno-prakticheskaya programma. Soyuz pediatrov Rossii, Mezhdunarodnyi fond okhrany zdorov'ya materi i rebenka [Acute Respiratory Diseases in Children: Treatment and Prevention. Theoretical and Practical Program. Union of Pediatricians of Russia, International Fund for Mother and Child Health Protection]. Moscow, 2004. 68 p.

2. Ovchinnikov A.Yu. Rossiiskaya otorinolaringologiya - Rissian otolaryngology. 2011; 5(54): 194-198.

3. Bykova V.P. Mindaliny limfadenoidnogo glotochnogo kol'tsa v sisteme mukozal'nogo immuniteta verkhnikh dykhatel'nykh putei [Lymphadenoid Tonsillar Ring Tonsils in the System of Mucosal Immunity of the Upper Respiratory Tract]. Tez. Vserossiiskoi konferentsii s mezhdunarodnym uchastiem «Problema reabilitatsii v otorinolaringologii» $i$ seminara "Aktual'nye voprosy foniatrii» (Abstracts of Russian National Conference with Imternational Participation "Rehabilitation in Otolaryngology" and Seminar "Relevant Issues of Phoniatrics"). Samara, 2003. pp. 344-345.

4. Volkov K.S., Nisevich L.L., Namazova-Baranova L.S., Filyanskaya E.G., Alekseeva A.A., Barannik V.A. Voprosy sovremennoi pediatrii-Current pediatrics. 2013; 12(1): 112-116. 5. Ikinciogullari A., Dogu F. Is immune system influenced by adenotonsillectomy in children? Int $J$ pediatr Otorhinolaryngol. 2002; 66(3): 251-257.

6. Kankasova M.N., Mokhova O.G., Pozdeeva O.S. Prakticheskaya meditsina-Practical medicine. 2009; 7(39): 55-62.

7. Tatochenko V.K. Bolezni organov dykhaniya u detei: prakticheskoe rukovodstvo. Izd. dop. [Diseases of Respiratory Organs in Children: Practice Guideline. Enlarged edition]. Moscow, Pediatr, 2012. $480 \mathrm{p}$.

8. Ebell M. H., Smith M. A., Barry H. C., Ives H. C., Carey M. The rational clinical examination. Does this patient have strep throat? JAMA. 2000; 284: 2912-8.

9. Boccazzi A., Garotta M., Pontari S., Agostoni C. V. Streptococcal tonsillopharyngitis: clinical vs. microbiological diagnosis. Infez Med. 2011; 19 (2): 100-5.

10. Kharina D.V., Macharadze D.Sh. Voprosy sovremennoi pediatrii-Current pediatrics. 2013; 12(5): 49-53.

11. McIsaac W., Kellner J., Aufricht P. et al. Empirical validation of guidelines for the management of pharyngitis in children and adults. JAMA. 2004; 291(13): 1587-1595.

12. Spichak T.V. Voprosy sovremennoi pediatrii - Current pediatrics. 2010; 9 (2): 130-135.

13. Kulichenko T.V., Patrusheva Yu.S., Redina A.A., Lazareva M.A. Pediatricheskaya farmakologiya - Pediatric pharmacology. 2013; 10(3): 38-43.

14. Gieseker K. et al. Evaluating the American Academy Pediatrics diagnostic standart for Streptococcus pyogenes pharyngitis: Backupculture versus repeat rapid antigen testing. Pediatrics. 2003; 111: 666-670.

15. Polunin M.M., Titarova L.S., Polunina T.V. Pediatricheskaya farmakologiya - Pediatric pharmacology. 2012; 9(3): 19-21.

16. Polunina T.A., Vishneva E.A. Pediatricheskaya farmakologiya-Pediatric pharmacology. 2011; 8(5): 106-108. 
17. Chiappini E., Principi N., Mansi N., Serra A., De Masi S. Management of acute pharyngitis in children: summary of the Italian National Institute of Health guidelines. Clin Ther. 2012; 34(6): 1442-1458.

18. Pelucchi C., Grigoryan L., Galeone C., Esposito S. Guideline for the mana gement of acute sore throat. Clin Microbiol Infect. 2012; 18(1): 1-28.

19. Septolete Neo. Instruktsiya po primeneniyu [Septolete Neo. Application].

20. Yachnikova M.A. Omskii nauchnyi vestnik - Omsk scientific bulletin. 2012; 2(114): 89-91.

Table 1. Etiology of acute tonsillites in children of various age groups (A.S. Darmanyan, 2010) $(\%)$

\begin{tabular}{|l|c|c|c|c|}
\hline \multirow{2}{*}{ Etiology } & \multicolumn{4}{c|}{ Age (years) } \\
\cline { 2 - 5 } & $\begin{array}{c}\mathbf{0 - 3} \\
\mathbf{n = 7 8}\end{array}$ & $\begin{array}{c}\mathbf{4 - 1 1} \\
\mathbf{n = 8 4}\end{array}$ & $\begin{array}{c}\mathbf{2} \mathbf{1 2} \\
\mathbf{n = 1 8}\end{array}$ & $\begin{array}{c}\text { Total } \\
\mathbf{n = 1 8 1}\end{array}$ \\
\hline Bacterial infections & 9 & 26 & 48 & 21 \\
\hline Viral infections & 56 & 49 & 26 & 50 \\
\hline Infectious mononucleosis & 35 & 25 & 26 & 29 \\
\hline
\end{tabular}

Table 2. The means of topical therapy of acute tonsillitis most frequently used in pediatric practice in the Russian Federation

\begin{tabular}{|c|c|c|c|c|c|c|}
\hline \multirow[t]{3}{*}{ Name } & \multirow[t]{3}{*}{ Formulation } & \multirow{3}{*}{$\begin{array}{l}\text { Pharmacological } \\
\text { action }\end{array}$} & \multicolumn{4}{|c|}{ Action spectrum } \\
\hline & & & \multicolumn{2}{|c|}{ Antimicrobial } & \multirow{2}{*}{ Antiviral } & \multirow{2}{*}{ Antifungal } \\
\hline & & & $\mathbf{G r}+$ & Gr- & & \\
\hline $\begin{array}{l}\text { Septolete } \\
\text { Neo (from } \\
4 \text { years of } \\
\text { age) }\end{array}$ & $\begin{array}{l}\text { Cetylpyridinium chloride } \\
1.2 \mathrm{mg}\end{array}$ & $\begin{array}{l}\text { Antiseptic drug } \\
\text { with antimicrobial, } \\
\text { antifungal and } \\
\text { viricidal action for } \\
\text { topical application }\end{array}$ & + & + & + & + \\
\hline $\begin{array}{l}\text { Faringosept } \\
\text { (from } \\
3 \text { years of } \\
\text { age) }\end{array}$ & Ambazone monohydrate $-10 \mathrm{mg}$ & $\begin{array}{l}\text { Antiseptic drug for } \\
\text { topical application }\end{array}$ & + & + & - & - \\
\hline $\begin{array}{l}\text { Strepsils (C } \\
\text { plus - from } \\
12 \text { years of } \\
\text { age, C and } \\
\text { vitamin C - } \\
\text { from } 5 \text { years } \\
\text { of age) }\end{array}$ & $\begin{array}{l}\text { Dichlorobenzyl alcohol - } 1.2 \mathrm{mg} \\
\text { Amylmetacresol - } 600 \mathrm{mcg}\end{array}$ & $\begin{array}{l}\text { Antiseptic drug for } \\
\text { topical application }\end{array}$ & + & + & - & + \\
\hline $\begin{array}{l}\text { Grammidin } \\
\text { Neo (from } \\
4 \text { years of } \\
\text { age) }\end{array}$ & $\begin{array}{l}\text { Gramicidin } \mathrm{C} \text { dihydrochloride - } \\
0.003 \mathrm{~g} \\
\text { Oxybuprocaine hydrochloride - } \\
0.0002 \mathrm{~g} \\
\text { Cetylpyridinium chloride } \\
\text { monohydrate }-0.001 \mathrm{~g}\end{array}$ & $\begin{array}{l}\text { Antibacterial and } \\
\text { antiseptic drug } \\
\text { with anesthetic } \\
\text { action }\end{array}$ & + & + & + & + \\
\hline $\begin{array}{l}\text { Falimint } \\
\text { (from } \\
6 \text { years of } \\
\text { age) }\end{array}$ & $\begin{array}{l}\text { Acetylaminonitropropoxybenzene } \\
-25 \mathrm{mg}\end{array}$ & $\begin{array}{l}\text { Drug with low } \\
\text { local anesthetic } \\
\text { and analgesic } \\
\text { action for topical } \\
\text { application }\end{array}$ & - & - & - & - \\
\hline
\end{tabular}

